\title{
Faktor-Faktor yang Memengaruhi Kinerja dan Kepuasan Tenan di Inkubator Bisnis IPB
}

\author{
Factors Influencing Performance and Satisfaction of Tenants in Business Incubator of IPB \\ Kristianingsih ${ }^{1 *}$, Ujang Sumarwan², dan Rokhani Hasbullah ${ }^{3}$ \\ ${ }^{123}$ Program Magister Sekolah Bisnis, Institut Pertanian Bogor \\ Jl. Raya Pajajaran Bogor, Bogor 16151
}

\begin{abstract}
ABSTRAK
Inkubator bisnis adalah suatu lembaga pendampingan bagi usaha pemula yang diyakini mampu menghasilkan wirausaha yang profesional, mandiri dan berdaya saing. Penelitian ini bertujuan mengidentifikasi faktor-faktor kinerja tenan inkubator bisnis dan mengevaluasi kepuasan tenan selama bergabung dengan inkubator bisnis. Penelitian dilakukan pada inkubator bisnis IPB dengan mewawancarai tenan inwall maupun outwall. Data dianalisis dengan pendekatan Wilcoxon test dengan program SPSS (Statistical Package for Social Science), IPA (Importance Performance Analysis) dan CSI (Customer Satisfaction Index). Hasil analisis menunjukkan bahwa kinerja tenan inwall dengan penambahan varian produk, jumlah pelanggan, keikutsertaan dalam pelatihan, adanya pendampingan usaha, dan perluasan tempat usaha. Tenan outwall mengalami keunggulan, yaitu omzet, laba, jumlah karyawan, perluasan pemasaran jumlah agen dan turunnya keluhan yang dialami tenan. Berdasarkan hasil perhitungan IPA dan CSI tingkat kepuasan tenan terhadap inkubator bisnis tergolong baik. Faktorfaktor yang dianggap perlu ditingkatkan oleh inkubator bisnis IPB adalah sumber daya memadai untuk peningkatan kinerja, terutama untuk pendampingan dan pelayanan terhadap tenan.
\end{abstract}

Kata kunci: inkubator bisnis, keputusan, kinerja, tenan, UKM

\begin{abstract}
Business incubator is an assistance agency for beginner business which is believed to be able to generate professional, independent, and competitive entrepreneurs. This research aims to identify factors influencing the performance of business incubator's tenants, and evaluate tenants's satisfaction during their participation in business incubator. This research is conducted in Business Incubator of IPB by interviewing both inwall tenants and outwall tenants. The data obtained are analyzed using, Wilcoxon test with SPSS software, Importance Performance Analysis (IPA) and Customer Satisfaction Index (CSI). Result of this research reveals that performance of inwall and outwall tenants are shown by the increase of gross profit, profit, number of employee, increase of product variants, number of customer, participation in training, the presence of business assistance, participation in training, the presence of business assistance, expansion of business place, expansion of business place. marketing expansion or number of agent, and the decline of complaints experienced by tenants. According to the calculation result of IPA,CSI, tenant satisfaction level on business incubator is categorized as good. Factor that is considered need to be improved by Business Incubator of IPB is adequate human resources performance improvement, especially for assistance and service toward tenants.
\end{abstract}

Key words: business incubator, decision, performance, tenant, SME

\footnotetext{
*) Korespondensi:

Gedung SB IPB- Jl. Raya Pajajaran Bogor, Bogor 16151, kristianingsih@gmail.com
} 


\section{PENDAHULUAN}

Setiap manusia yang baik dan bertanggungjawab akan mempunyai cita-cita dan keinginan kuat dalam memenuhi kebutuhan dalam kehidupannya dengan cara bekerja di suatu tempat, lembaga, instansi, perusahaan maupun mengusahakan bisnis pribadi. Pendampingan usaha ataupun UKM (Usaha Kecil Menengah) perlu dilakukan secara komperehensif menyangkut seluruh aspek baik teknis, manajemen, modal usaha, administrasi. Salah satu pendampingan usaha adalah inkubator bisnis, strategi paling efektif adalah melalui model pendampingan partisipatif melalui inkubator bisnis (Hasbullah et al. 2014). Skema pembentukan wirausaha melalui inkubator bisnis dapat dilihat pada Gambar 1 . Calon wirausaha diseleksi oleh inkubator bisnis dan dibina dengan cara mengenal pasar, teknologi, modal, informasi, manajemen dalam suatu wadah inkubasi bisnis (inkubator) sehingga usaha tersebut akan bertumbuh menjadi pengelola usaha kecil profesional dan modern.

Jumlah inkubator bisnis dan pertumbuhannya di Indonesia masih cukup jauh tertinggal dibandingkan dengan negara-negara lain. UniEropa memiliki 1.100 inkubator bisnis dengan rataan jumlah tenan 25 per inkubator. China memiliki 450 Inkubator binis, dengan rataan jumlah tenan 36 per inkubator bisnis (BI 2006). Jumlah inkubator bisnis di Indonesia diperkirakan sebanyak 50 inkubator bisnis (pemerintah, universitas, maupun swasta). Salah satu inkubator bisnis di Indonesia yang sudah dianggap berprestasi baik adalah inkubator bisnis Institut Pertanian Bogor (IPB). Prestasi yang sudah pernah diraih inkubator IPB antara lain mendapat penghargaan dari Kementrian Koperasi dan Usaha Kecil Menengah (Kemkop UKM) sebagai pengelolaan inkubator wirausaha terbaik di tahun 2015 dan penghargaan dari Universitas Sebelas Maret (UNS) sebagai inkubator bisnis pengembang UKM terbaik.

Inkubator Bisnis IPB harus terus menerus menjaga kepercayaan dari pelanggan internal (tenan) dan juga dari pelanggan luar (instansi, investor, pemerintah, masyarakat, dll). Pihak luar inkubator bisnis seperti pemerintah mempunyai peranan untuk menyukseskan program inkubator bisnis dengan sumber daya bermutu yang bermacam-macam dari daerah. Selama ini belum ada pemaparan tesis yang memungkinkan inkubator bisnis IPB menyusun strategi berdasarkan keputusan, kinerja dan pentingnya kepuasan pelanggan pada inkubator bisnis IPB. Inkubator bisnis IPB memerlukan data yang mendukung faktor-faktor keputusan, kinerja dan evaluasi kepuasan tenan agar bisa didapatkan strategi baru dan implikasi manajerial yang bisa diterapkan berbagai pihak berkepentingan bagi kemajuan inkubator bisnis. Tujuan penelitian topik inkubator ini dapat dijadikan rujukan/acuan bagi inkubator bisnis IPB dan inkubator lainnya di Indonesia untuk meningkatkan jumlah tenan di inkubator bisnis sebagai salah satu dukungan pada peningkatan jumlah UKM di Indonesia.

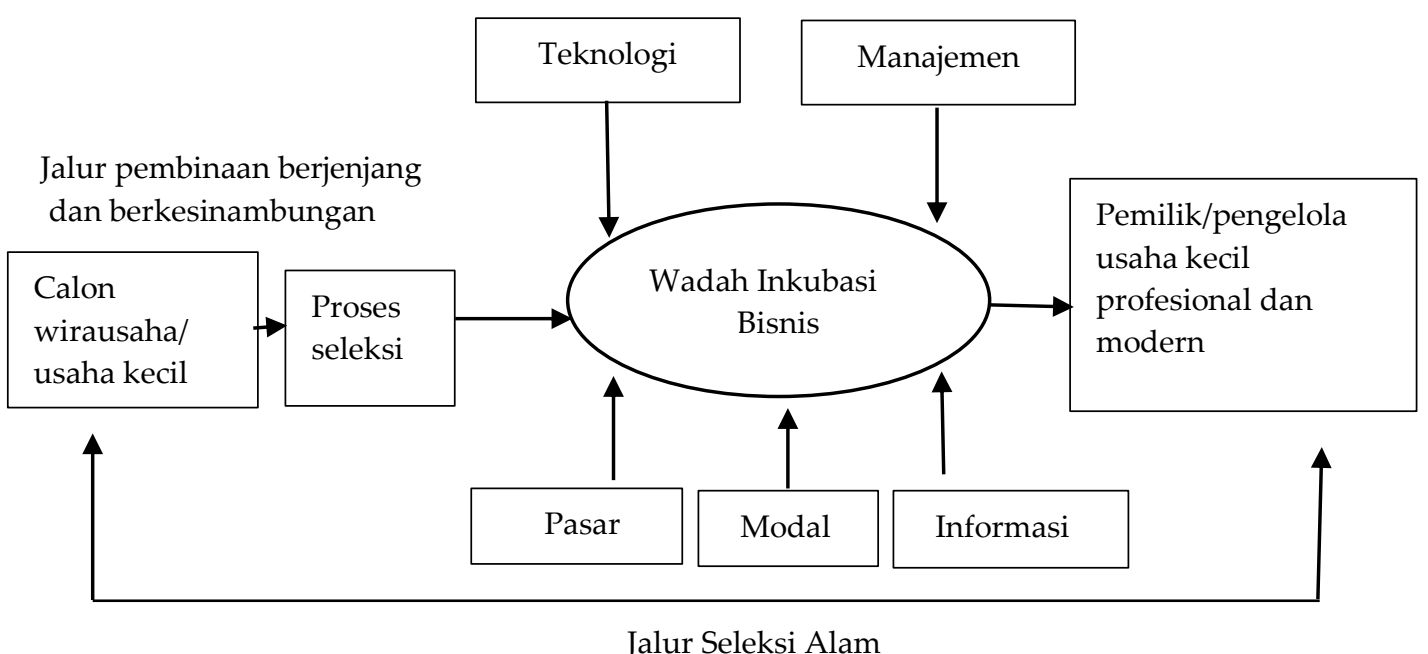

Sumber: Hubeis (2011).

Gambar 1. Pembentukan wirausahawan melalui wadah inkubator bisnis 
Beragam penelitian terkait inkubator bisnis dan organisasi lainnya termasuk di dalamnya adalah pengukuran kinerja dalam inkubator bisnis, kinerja IPA (Importance Performance Analysis), CSI (Customer Satisfaction Index), kepuasan pelanggan, wirausaha dan inkubator bisnis telah dilakukan oleh berbagai pihak. Berdasarkan literatur yang diperoleh dikelompokkan sebagai berikut:

\section{Pengukuran Kinerja dalam Inkubator Bisnis}

Kinerja inkubator ditunjukkan dari keberhasilan programnya, pertumbuhan pendapatan, karyawan atau kreasi pekerjaan, dana perusahaan, jaringan dan bangunan berdampak ke proses inkubasi bisnis. Penelitian merekomendasikan kandidat yang berpotensial adalah inkubator yang memperbaiki pasarnya, management dan perencanaan keuangan untuk meningkatkan kesempatannya dalam seleksi tenannya (Ayatse et al., 2017; Calza et al., 2014; Khorsheed et al., 2014).

Banyak penelitian mengembangkan model untuk evaluasi bisnis inkubator bisnis agar efektif dan spesifik manajemen inkubator bisnis dan tenaga ahlinya seharusnya dapat mengevaluasi inkubator bisnis, memberikan training dan pelatihan yang menjadi jawaban spesifik bagi tenan sesuai kebutuhan tenan yang berbeda-beda (Calza et al. 2014; Xu, 2010; Mungai dan Njeru, 2013). Reed (1991) mengidentifikasi inkubator di kota kecil lebih sukses daripada inkubator di kota metropolitan. Secara sistemik, inkubator bisnis merupakan suatu wahana transformasi pembentukan Sumber Daya Manusia (SDM) yang tidak atau kurang kreatif dan produktif menjadi SDM yang memiliki motivasi wirausaha secara kreatif, inovatif, produktif dan kooperatif sebagai langkah awal dari penciptaan wirausaha yang memiliki keunggulan kompetitif dan komparatif serta memiliki visi dan misi (Ilyas, 2016).

\section{Kinerja IPA dan CSI}

Berdasarkan hasil IPA maka pada umumnya di setiap atribut masih terdapat kesenjangan antara tingkat kepentingan dan tingkat kinerja dimana peubah dependen adalah kepuasan pelanggan dan peubah independen meliputi dimensi bukti langsung, kehandalan, daya tanggap, jaminan, empati (Setiawan, 2003; Agisty, 2005; Riyanto dan Riyanto, 2015). Peubah dimensi terdiri dari lima dimensi yakni tangible, reliability, responsiveness, assurance, dan empathy (Zeithaml et al. 1990).

Masing-masing dimensi disusun oleh komponen peubah pembentuknya yang disebut dengan indikator. Analisis servqual (service quality) yang terdiri dari lima dimensi mutu jasa, yaitu (a) bukti fisik (tangibles), (b) kehandalan (reliability) kemampuan perusahaan memberikan pelayanan sesuai yang dijanjikan secara akurat dan terpercaya, (c) ketanggapan (responsiveness), (d) jaminan dan kepastian (assurance) pengetahuan, kesopan-santunan dan kemampuan dan (e) perhatian yang tulus (empathy) (Riyanto dan Riyanto, 2015; Setiawan, 2003; Agisty, 2005).

\section{Kepuasan Pelanggan}

Inkubator bisnis perlu memfokuskan dukungan keuangan pada kliennya (tenan) yang dilayani terutama untuk teknologi dan bagian Research and Development (R\&D) bagian pengembangan produk (Kilcrease, 2011). Pelayanan paling penting menurut tenan karena tenan sangat membutuhkannya, pelayanan mempengaruhi kesuksesan tenan untuk mencapai tujuannya yaitu pelayanan inkubator tergantung fasilitas inkubator bisnis (Reed, 1991).

\section{Inkubator Bisnis}

Hasil penelitian menunjukkan faktor sukses dari inkubator bisnis adalah adanya inovasi sebagai budaya para pelaku usaha, kerjasama yang baik antara universitas, teknologi inkubator bisnis dan pemerintahan, keahlian para karyawan, faktor lingkungan, perusahaan yang inovasi dan visi bersama di inkubator bisnis, inkubator merespon kebutuhan lokal, bagaimana membentuk struktur lokal, kreasi bisnis baru dan perkembangan ekonomi (Kharabesheh, 2012) (Meru and Struwig, 2015). Penelitian membantu manager inkubator bisnis, pembuat kebijakan dan pemerintah sukses dalam mengimplementasikan kebijakan inkubator bisnis (Oliveira dan Vieira, 2016; Reed, 1991).

Tujuan penelitian kinerja tenan inwall dan outwall sebelum dan sesudah bergabung dengan Inkubator Bisnis IPB adalah membuktikan adanya perbedaan kenaikan kinerja positif karena bergabungnya tenan dalam inkubator bisnis IPB, sedangkan tingkat kepuasan diharapkan tenan mendapatkan kepuasan setelah bergabung dengan Inkubator Bisnis IPB.

\section{METODE PENELITIAN}

Penelitian ini dilaksanakan di inkubator bisnis IPB yang berlokasi di Leuwilokopo, Darmaga, Bogor dan juga lokasi tenan outwall (diluar gedung). Desain penelitian adalah studi kasus dan teknik pengumpulan data dan informasi melalui diskusi, wawancara dengan 
kuesioner dan studi pustaka. Pemilihan responden dilakukan dengan teknik purposive sampling untuk memilih tenan inkubator baik inwall (beraktivitas dalam gedung) dan outwall (luar gedung) yang masih ada didalam inkubator bisnis IPB dengan minimal lamanya satu tahun keanggotaan dipilih, karena dianggap angkatan tersebut sudah memiliki hasil perbedaan pencapaian sebelum dan sesudah masuk inkubator bisnis IPB dan masih memiliki ingatan yang kuat pada proses kemajuannya. Total tenan yang diberikan kuesioner adalah 31 tenan dari data 40 tenan tersedia dari inkubator bisnis IPB. Skala pengukuran yang digunakan pada penelitian ini adalah skala likert untuk mengukur persepsi dan sikap tenan pada saat proses pengisian kuesioner. Kerangka pemikiran penelitian ini dapat dilihat pada Gambar 2.

\section{HASIL DAN PEMBAHASAN}

\section{Kinerja Tenan Inkubator Bisnis}

Penting melihat kinerja inkubator bisnis dari sudut pandang pelayanan dan sumber daya inkubator bisnis dimana tenan proaktif sebagai jaringan lingkungan dari inkubator mempunyai pengaruh yang nyata positif pada kepuasan inkubator (Adlešič dan Slavec, 2012). Kinerja tenan sebelum dan sesudah masuk inkubator bisnis disajikan pada Tabel 1 .

Perbedaan pendampingan tenan inwall dan outwall dilihat dari kriteria inovasi produk dan pelatihan. Inovasi produk untuk tenan outwall lebih nyata dibandingkan tenan inwall, hal ini dikarenakan keterbatasan fasilitas yang ada untuk tenan inwall, dan untuk tenan outwall lebih memiliki kebebasan berinovasi. Peningkatan jumlah pelatih- an nyata pada tenan inwall, sedangkan tenan outwall tidak nyata dikarenakan tenan outwall lebih sulit mengatur waktu (sibuk) diluar sehingga jarang mengikuti pelatihan.

\section{Omzet}

Inkubator bisnis telah berperan dalam peningkatan kinerja usaha tenan, dimana UKM tenan mengalami peningkatan jumlah tenaga kerja, peningkatan omzet, perluasan wilayah pemasaran dan peningkatan akses ke sumber permodalan (Hasbullah et al., 2014). Lebih baik lagi jika pengelola keuangan dan modal usaha menjadi sebuah hal menarik bagi investor untuk proses pendanaan dan kerjasama pemerintah, sehingga nantinya dapat menunjukkan perbaikan indikator ekonomi (Pallares, 2012). Pemimpin yang ingin mengembangkan ekonomi harus banyak memahami inkubator bisnis dan harus banyak mengerjakan tugas atau program besar yang dicocokkan ke dalam sistem, sehingga program inkubator dapat tercampur dengan baik dalam program daerahnya sehingga bersatu dan menjadi berkembang (O'neal, 2005).

Laba

Pada tingkat Inwall ada perubahan kenaikan laba sebelum masuk inkubator dan sesudah masuk inkubator. Besar perubahan 2,12 kali lipat untuk tenan inwall dan 3,69 kali lipat untuk outwall. Hal ini menunjukkan masuknya wirausaha dalam inkubator menghasilkan pengaruh positif bagi laba wirausaha. Agar mendapatkan laba yang optimal, pengelola perusahaan cenderung menggunakan berbagai cara untuk memperbaiki kinerja hasil pemasaran dan kebijakan akuntansi yang dapat menguntungkannya.

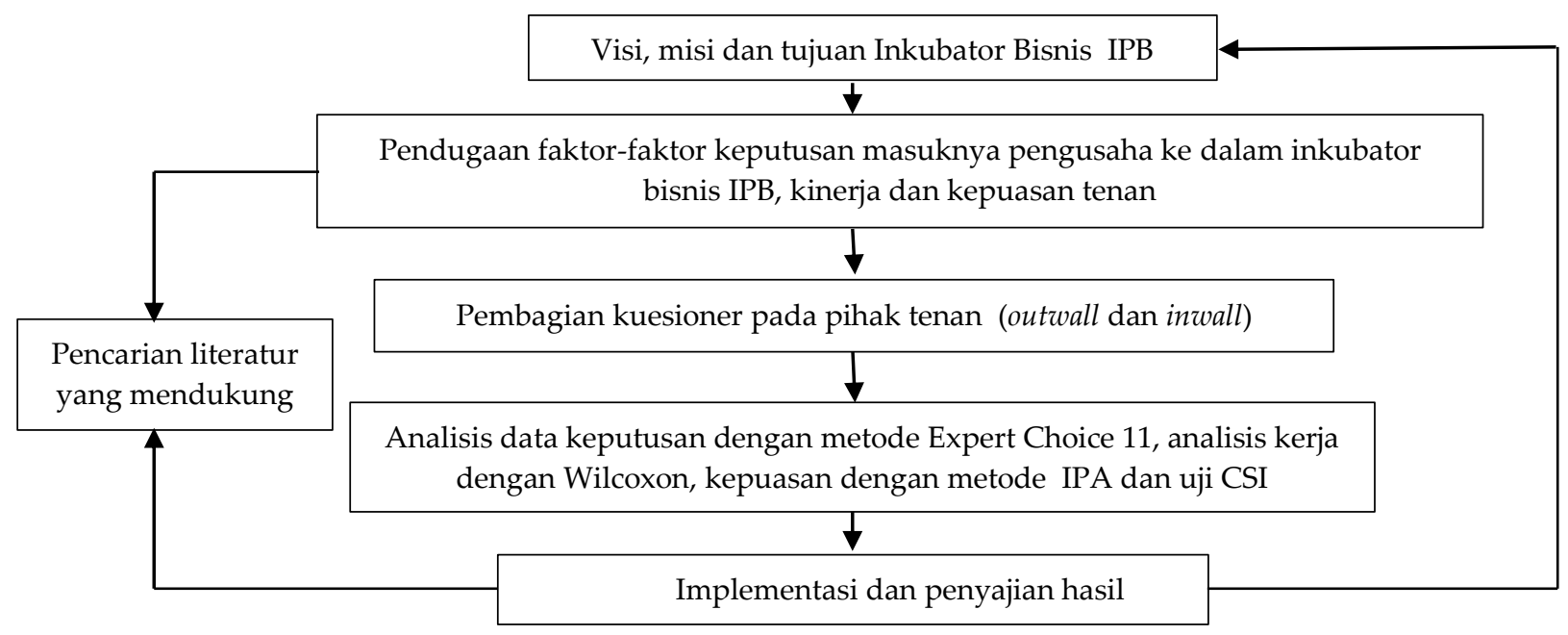

Gambar 2. Kerangka pemikiran 
Tabel 1. Kinerja usaha tenan inkubator bisnis IPB

\begin{tabular}{|c|c|c|c|c|c|c|}
\hline \multirow[b]{2}{*}{ Kriteria } & \multicolumn{3}{|c|}{ Inwall } & \multicolumn{3}{|c|}{ Outwall } \\
\hline & Sebelum & Sesudah & $\begin{array}{l}\text { Kenaikan } \\
\text { (kelipatan) }\end{array}$ & Sebelum & Sesudah & $\begin{array}{l}\text { Kenaikan } \\
\text { (kelipatan) }\end{array}$ \\
\hline Omzet per bulan (juta) & 23,13 & $47,56^{* *}$ & 2,06 & 28,89 & $96,81^{* *}$ & 3,67 \\
\hline Laba per bulan (juta) & 5,59 & $11,83^{* *}$ & 3,69 & 10,17 & $30,68^{* *}$ & 3,69 \\
\hline $\begin{array}{l}\text { Jumlah karyawan per } \\
\text { tahun (orang) }\end{array}$ & 4 & $7^{* *}$ & 2,04 & 6 & $12^{* *}$ & 2 \\
\hline $\begin{array}{l}\text { Jumlah inovasi produk } \\
\text { per tahun (unit) }\end{array}$ & 3 & $5^{\text {th }}$ & 1,69 & 4 & $7^{* *}$ & 1,75 \\
\hline $\begin{array}{l}\text { Jumlah pelanggan per } \\
\text { tahun (orang) }\end{array}$ & 20 & $49^{* *}$ & 2,45 & 61 & $118^{* *}$ & 1,93 \\
\hline $\begin{array}{l}\text { Jumlah keikutsertaan } \\
\text { pelatihan per tahun (hari) }\end{array}$ & 2 & $4^{*}$ & 2 & 3 & $5^{\text {tn }}$ & 1,67 \\
\hline $\begin{array}{l}\text { Jumlah banyaknya } \\
\text { pendampingan } \\
\text { per tahun (orang) }\end{array}$ & 0 & $2^{* *}$ & 2 & 0 & $2^{*}$ & 2 \\
\hline $\begin{array}{l}\text { Perluasan tempat usaha } \\
\text { per tahun ( unit lokasi) }\end{array}$ & 1 & $2^{* *}$ & 2 & 1 & $2^{* *}$ & 2 \\
\hline $\begin{array}{l}\text { Perluasan pemasaran } \\
\text { jumlah agen per tahun } \\
\text { (unit agen) }\end{array}$ & 2 & $5^{* *}$ & 2,5 & 4 & $11^{* *}$ & 2,75 \\
\hline $\begin{array}{l}\text { Jumlah komplain per } \\
\text { tahun (unit kasus) }\end{array}$ & 1 & $2^{\text {tn }}$ & 2 & 2 & $2^{\text {tn }}$ & 0 \\
\hline
\end{tabular}

Keterangan: ${ }^{* *}$ ) Nyata pada taraf $1 \%$; ) Nyata pada taraf $5 \%$; ${ }^{\text {tn }}$ ) tidak nyata

\section{Jumlah Karyawan}

Perubahan kenaikan jumlah karyawan sebelum masuk inkubator dan sesudah masuk inkubator. Besar perubahan inwall adalah 1,90 kali lipat dan untuk outwall adalah 2.04 kali lipat. Hasil kenaikan karyawan lebih besar di tenan outwall dibandingkan di inwall karena memang laba, omzet dari tenan outwall lebih besar, sehingga bisa membayar karyawan lebih banyak dan baik lagi.

\section{Jumlah Inovasi}

Produk inovasi dapat gagal karena banyak kesalahan, dimana salah satu kesalahannya dalam menerapkan strategi menjadi sebab yang sering terjadi, desain produk yang tidak inovatif, salah memperkirakan persaingan, masalahnya terletak pada desain atau biaya produksinya jauh lebih tinggi dari yang diperkirakan. Bisa dilihat bahwa lebih besar inovasi dilakukan di inwall, karena waktu berinovasi lebih bisa dilakukan selama dalam gedung, untuk inovasi bisa mendapatkan tenaga bimbingan dari tenan dan pendampingan dari inkubator langsung.

\section{Jumlah Pelanggan}

Masuknya wirausaha yang berhasil dalam inkubator berhasil menaikan jumlah pelanggan sehingga berakibat menaikkan omzet.

\section{Keikutsertaan dalam Pelatihan}

Pada tingkat Inwall ada kenaikan jumlah pelatihan sebelum masuk inkubator dan sesudah masuk inkubator, sebesar dua kali lipat dan 1.67 kali lipat di outwall. Tenan inwall semakin banyak mengikuti pelatihan akan lebih mempunyai banyak keahlian yang diperlukan di dunia usaha misalkan menghitung HPP (Harga Pokok Produksi), berlatih cara memasarkan, cara memilih kemasan dan cara membuat proposal, sehingga nantinya tenan akan lebih berhasil menaikan jumlah pelanggan sehingga berakibat menaikkan omzet.

\section{Pendampingan Usaha}

Kepuasan tenan di inkubator bisnis IPB masih didominasi banyaknya ketidakpuasan untuk jumlah pendampingan yaitu meminta untuk pendampingan lebih ditingkatkan. Faktor pendampingan usaha dari tenan mengharapkan lebih diperhatikan.

\section{Perluasan Tempat Usaha}

Perubahan kenaikan jumlah tempat usaha pada inwall sebelum masuk inkubator dan sesudah masuk inkubator hampir sama yaitu sebesar dua kali lipat. Hal ini berarti masuknya wirausaha yang berhasil dalam inkubator, sehingga ada uang untuk membuka usaha baru sebagai tempat usaha baru. Tempat usaha tenan 
inwall memperhitungkan ruangan di inkubator yang biayanya rendah hanya saja butuh konsistensi untuk mengecek, apakah lokasi usaha di dalam gedung sudah dimanfaatkan secara baik. Tempat usaha di rumah juga dianggap lebih fleksibel, karena bisa dilakukan usaha sembari menjalankan pekerjaan rumah tangga dan mengurus keluarga tenan.

\section{Jumlah Outlet Pemasaran}

Pada kategori outwall terdapat jumlah agen yang meningkat ini, hal ini sangat baik dalam pemasaran, sehingga produk atau jasa dari wirausaha bisa cepat dikenal di masyarakat. Hal ini karena ada penambahan agen mengakibatkan omzet bertambah besar, laba tenan semakin besar. Suryana dan Bayu (2010) mengemukakan seorang wirausaha tidak dapat hidup sendiri dalam menjalankan usahanya, ada keterkaitan dengan pihak luar baik sebagai pemasok, pelanggan, maupun pedagang perantara. Suatu jaringan usaha diperlukan, agar usaha yang dijalankan berkelanjutan dan terus dipasarkan. Jaringan usaha dan komunikasi terbukti berperan penting dalam pengembangan usaha. Tenan diharapkan semakin memperluas jaringan usaha sesuai dengan tujuannya menjadi tenan di inkubator bisnis.

\section{Keluhan yang dialami Tenan}

Jumlah keluhan yang meningkat ini masih harus diturunkan, karena kalau terus menerus ada keluhan maka keinginan membeli dan kepercayaan masyarakat akan menurun. Keluhan kepada suatu produk harus ditangani dengan serius dan terus menerus. Kepuasan pelanggan bersifat relatif dan selalu berubah sesuai dengan kebutuhan pelanggannya (Barus, 2010).

\section{Kepuasan Tenan pada Inkubator Bisnis IPB}

Kepuasan tenan pada inkubator bisnis memberikan kontribusi pengaruh jaringan kerja pada kepuasan inkubator bisnis (Adlešič dan Slavec, 2012). Dalam suatu proses keputusan, konsumen tidak akan berhenti hanya sampai proses konsumsi, tetapi konsumen akan melaku- kan proses evaluasi terhadap konsumsi yang telah dilakukannya (Sumarwan, 2011). Nilai CSI dapat dilihat pada Tabel 2 dibahas satu per satu dari setiap peubah dan hasilnya secara keseluruhan anggota inkubator lebih puas tenan inwall dibandingkan dengan tenan outwall.

Hasil penelitian menunjukkan pada tangible nilai CSI inwall $70.03 \%$ dan tenan outwall $69,88 \%$, ini berarti lebih puas pihak tenan inwall dibandingkan tenan outwall. Realibility nilai CSI inwall $74,83 \%$ dan tenan outwall $72,95 \%$, hal ini berarti lebih puas pihak tenan inwall dibandingkan tenan outwall. Hasil penelitian menunjukkan responsiveness nilai CSI inwall $75,03 \%$ dan tenan outwall $72,04 \%$. Hal ini berarti lebih puas pihak tenan inwall dibandingkan tenan outwall. Hasil CSI untuk assurance pada tenan inwall 76,07\% dan pada tenan outwall $75,37 \%$. Saran dari tenan outwall kebanyakan ingin mendapatkan pelatihan lebih intensif dari segi pengurusan surat, perijinan, perpajakan dan juga pelatihan yang lebih banyak lagi. Indikator emphaty merupakan indikator terakhir yang berpengaruh terhadap kepuasan. Hasil CSI untuk emphaty pada tenan inwall sebesar $73,04 \%$ dan pada tenan outwall sebesar $69,71 \%$.

Gambar 3 menunjukkan data hasil IPA tenan outwall didalam diagram Kartesius yang terbagi dalam empat kuadran dan tiap kuadran menunjukkan terjadi suatu kondisi yang berbeda dengan kuadran lainnya. Hal yang perlu dilakukan perbaikan di pelayanan tenan outwall dalam inkubator bisnis IPB antara lain keinginan tenan untuk penanganan masalah kondisi sarana alat training di inkubator bisnis (X1.2), website inkubator bisnis (X1.6), kepedulian inkubator pada mutu barang/jasa tenan (X2.4), penanganan keluhan (X2.9), pendampingan tenan (X2.10), kesediaan inkubator menolong tenan (X3.4), sikap inkubator terhadap saran tenan (X3.8), jaminan produk jasa ijin tepat (X4.8), pemahaman kebutuhan keahlian (X5.3) dan kesungguhan inkubator pada kemajuan tenan (X5.8).

Tabel 2. Hasil CSI pada tenan inwall dan tenan outwall

\begin{tabular}{lccl}
\hline \multicolumn{1}{c}{ Variabel } & CSI tenan inwall & CSI tenan outwall & Keterangan \\
\hline Tangible & 70,03 & 69,88 & Pada lima peubah yang \\
Realibility & 74,83 & 72,95 & diukur, nilai CSI tenan \\
Responsiveness & 75,03 & 72,04 & inwall lebih tinggi \\
Assurance & 76,07 & 75,37 & dibandingkan tenan \\
Emphaty & 73,04 & 69,71 & outwall \\
\hline
\end{tabular}




\section{IPA tenan outwall}

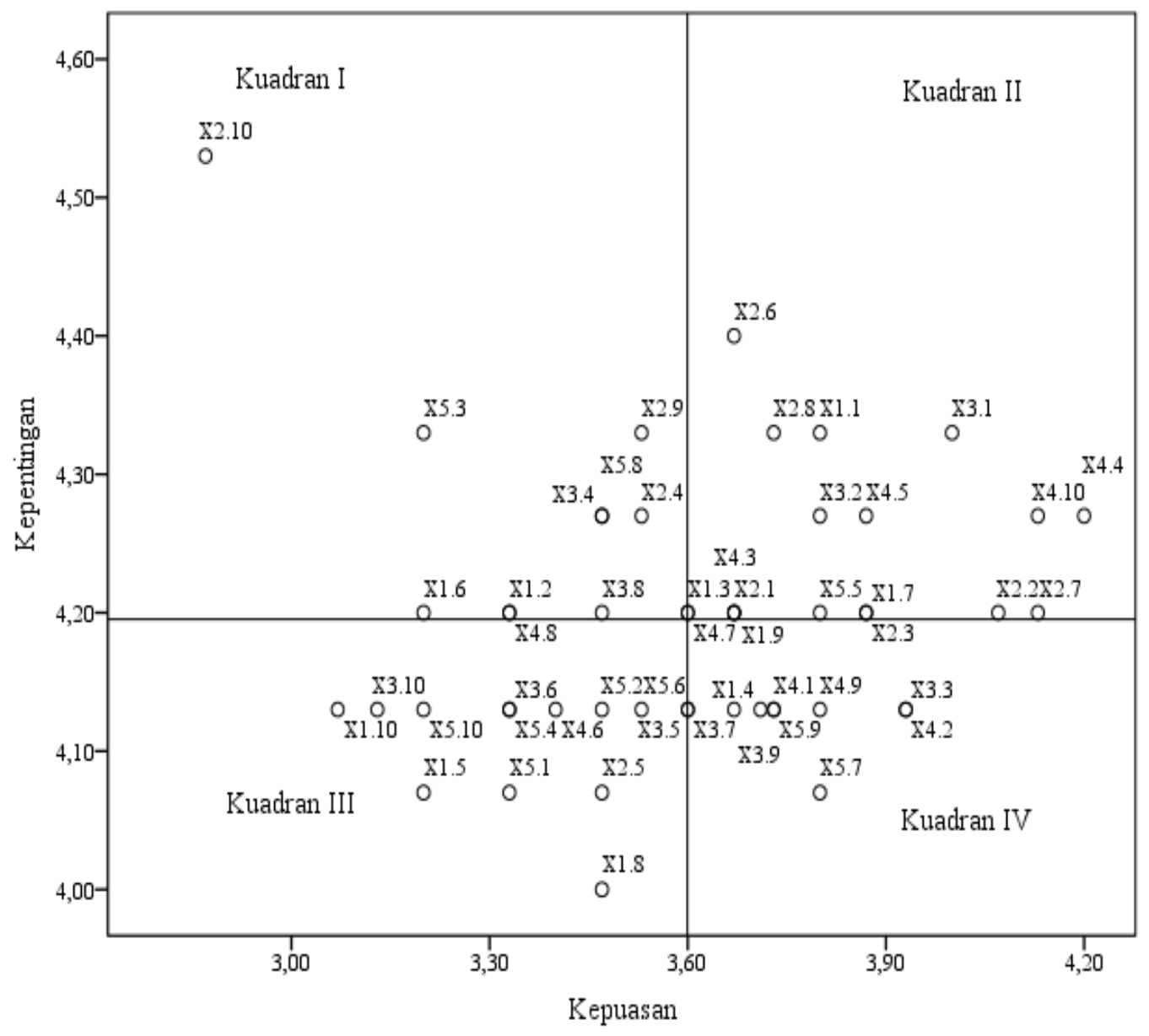

Gambar 3. Hasil IPA tenan outwall

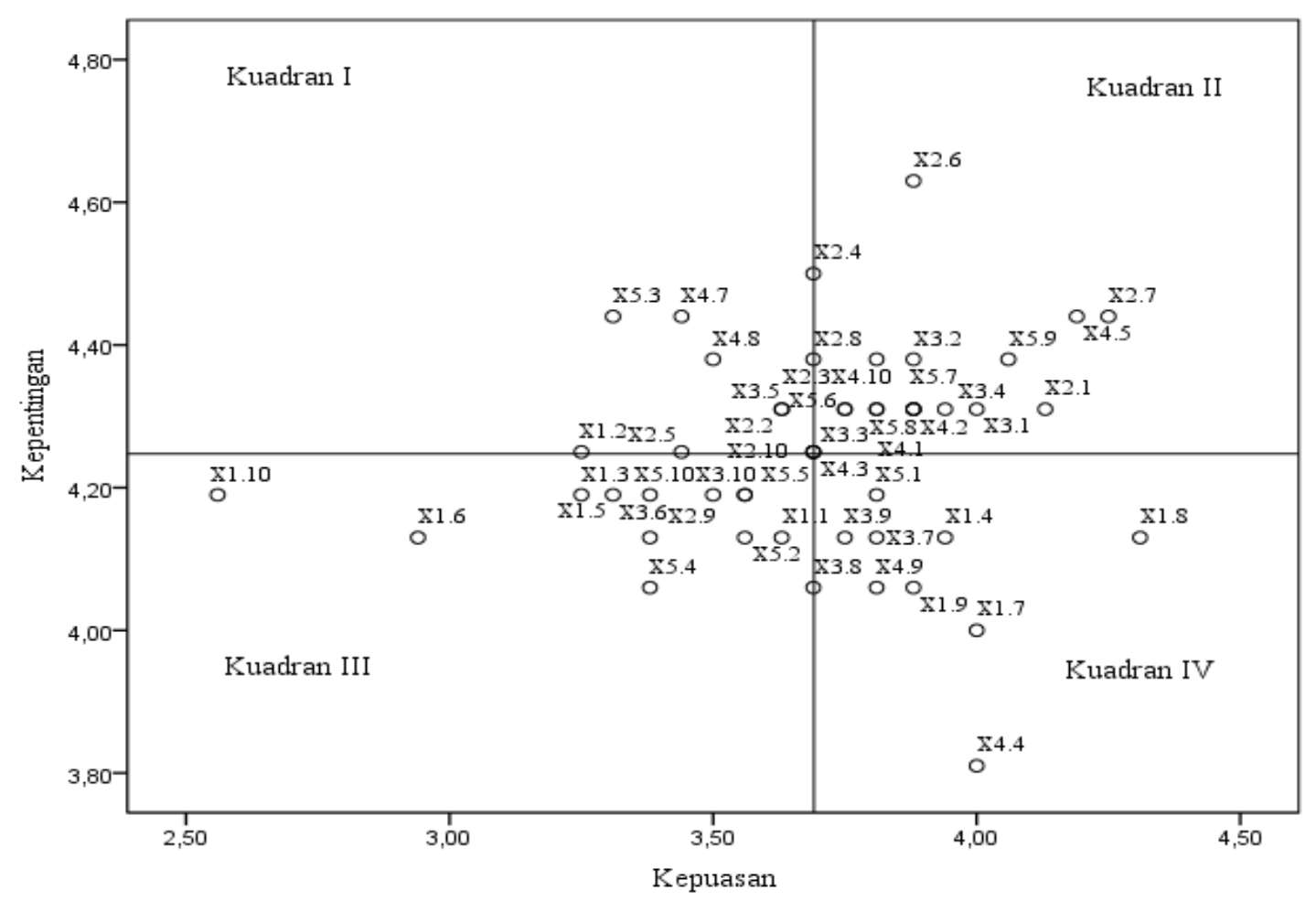

Gambar 4. Hasil IPA tenan inwall 


\section{IPA tenan Inwall}

Hasil penilaian yang dilakukan oleh anggota inkubator inwall terhadap kinerja pegawai inkubator menunjukkan tingkat kepuasan anggota inkubator inwall secara keseluruhan terhadap perusahaan memiliki CSI lebih tinggi dari tenan outwall. Penilaian ini sesuai dengan pendapat berbagai pihak instansi kepada inkubator bisnis IPB, ditunjukkan dengan berbagai kunjungan yang datang pada inkubator bisnis IPB untuk studi banding, pembelajaran, diskusi dll. Tenan inwall pada inkubator bisnis IPB merasa puas karena fasilitas pelatihan dan ruangan yang didapatkan sudah baik dan terjangkau.

\section{KESIMPULAN}

Berdasarkan hasil analisis kinerja maka ada perbedaan kinerja (omzet, laba, jumlah karyawan, inovasi produk, jumlah pelanggan, keikutsertaan pelatihan, pendampingan usaha, perluasan tempat usaha, perluasan pemasaran jumlah agen, dan komplain yang dialami tenan) sebelum dan sesudah masuk inkubator bisnis. Kinerja usaha tenan inwall dan outwall mengalami kenaikan setelah bergabung dengan inkubator bisnis IPB. Hasil uji Wilcoxon menunjukkan kinerja tenan inwall sebelum dan sesudah mengalami peningkatan yang signifikan diantaranya omzet, laba, karyawan, pelanggan, pelatihan, pendampingan, tempat usaha, perluasan pemasaran jumlah agen.

\section{UCAPAN TERIMAKASIH}

Terimakasih disampaikan kepada Inkubator Bisnis IPB (Incubie) yang telah memberikan kesempatan untuk penelitian ini sehingga datanya dapat dipakai pada penelitian dan bisa dijadikan penambahan wawasan dan memotivasi tenan agar dapat berkarya lebih banyak.

\section{DAFTAR PUSTAKA}

Adlešič, RV., A. Slavec. 2012. Social Capital and Business Incubators Performance: Testing the Structural Model. Journal Economic and Business Review. 14(3):201-221.

Agisty, S. 2005. Analisis Kepuasan Nasabah terhadap Kualitas Pelayanan ATM BNI (Kasus pada Nasabah BNI Cabang Utama Juanda Bogor). [tesis]. Bogor (ID): Institut Pertanian Bogor.
Ayatse, FA., N. Kwahar, AS. Iyortsuun. 2017. Business Incubation Process and Firm Performance: an Empirical Review. Journal of Global Entrepreneurship Research. 7(2): 1-17.

Barus, MA. 2010. Analisis Kepuasan dan Loyalitas Pelanggan FIT (Free Individual Traveller) Hotel Salak The Heritage Bogor. [tesis]. Bogor (ID): Institut Pertanian Bogor.

Bank Indonesia. 2006. Kajian Inkubator Bisnis dalam rangka Pengembangan UMKM. Jakarta (ID): Tim Penelitian dan Pengembangan Biro Kredit BI.

Calza, F., L. Dezi, F. Schiavone, M. Simoni. 2014. The Intellectual Capital of Business Incubators. Journal of Intellectual Capital. 15(4): 597-610.

Hasbullah, R., M. Surahman, A, Yani, DP. Almada, EN. Faizaty. 2014. Model Pendampingan UMKM Pangan Melalui Inkubator Bisnis Perguruan Tinggi. Jurnal Ilmu Pertanian Indonesia (JIPI). 19(1):43-49.

Hubeis, M. 2011. Prospek Usaha Kecil dalam Wadah Inkubator Bisnis. Bogor (ID): Ghalia Indonesia

Ilyas, A. 2016. Strategi Pengembangan Produksi Animasi PT AYENA MANDIRI SINEMA (Kasus Tenant di Balai Inkubator Teknologi BPPT). [tesis]. Bogor (ID): Institut Pertanian Bogor.

Kharabesheh, R. 2012. Critical Success Factors of Technology Parks in Australia. International Journal of Economics and Finance. 4 (7):57-66.

Khorsheed, MS., MA. Al-Fawzan, A. Al-Hargan. 2014. Promoting techno-entrepreneurship through incubation: An overview at BADIR program for technology incubators. Journal Innovation: Management, Policy \& Practice. 16(2):238-249.

Kilcrease, KM. 2011. Multi-factor Assessment of Service Delivery in Business Incubators: Perspectives from Incubator Tenants. Journal of Applied Management and Entrepreneurship. 16(2): 80-95.

Meru, AK., M. Struwig. 2015. Business-Incubation Process and Business Development in Kenya: Challenges and Recommendations. Journal of Entrepreneurship andInnovation in Emerging Economies 1(1):1-17.

Mungai, DN., A. Njeru. 2013. Effect of Business Incubator Services on Performance of Business Ventures at Nairobi Incubation Lab, Kenya. International Journal of Science and Research.5(5):1500-1506. 
O'neal, T. 2005. Assessing the Impact of University Technology Incubator Practices on Client Performance [disertasi]. Orlando, Florida: University of Central Florida.

Oliveira, SRM., MT. Vieira. 2016. Empirical Evidence About the Characteristics and Business Incubators Performance: a Framework of Multiple Cases. American International Journal of Contemporary Research. 6(1):62-70.

Pallares-Venegaz, E. 2012. The Effect of Incubator Participation in Developed Market Direct Entry by Emerging Market Firms [Disertasi]. El paso: Universitas of Texas.

Reed, D. 1991. Incubator Program: Factors in a Profile of Success. Journal of Business and Entrepreneurship. 3(1):61-71.

Riyanto, AH., B. Riyanto. 2015. Analisis Peningkatan Pelayanan Stasiun Bogor Terhadap Kepuasan Pengguna Jasa Kereta Api dengan Metode Importance Performance Analysis (IPA). Jurnal Pembangunan Wilayah dan Kota. 11(4): 391-402.
Setiawan, A. 2003. Strategi Optimalisasi Kinerja serta Produktifitas Agen Roti guna Meningkatkan Daya Saing Produsen Roti. Studi Kasus di PT Pangan Rahmat Buana Bogor. [tesis]. Bogor (ID): Institut Pertanian Bogor.

Sumarwan, U. 2011. Perilaku Konsumen Teori dan Penerapannya dalam Pemasaran. Bogor (ID): Ghalia Indonesia.

Suryana, Y., K. Bayu. 2010. Kewirausahaan Pendekatan Karakteristik Wirausahawan Sukses. Jakarta (ID): Kencana Prenada Media Grup.

$\mathrm{Xu}, \mathrm{L}$. 2010. Business incubation in China Effectiveness and perceived contributions to tenant enterprises. Management Research Review. 33(1):90-99.

Zheithaml, VA., A. Parasuraman, and LL. Berry. 2015. Delivering Quality Services, Balancing Customer Perceptions and Expectations. New York USA: The Free Press. 